\title{
Practising Reflection: Empathy, Emotion and Intuition in Political Life
}

Writing

\section{Jack Corbett}

State, Society and Governance in Melanesia

School of International, Political \& Strategic Studies

ANU College of Asia \& the Pacific

Australian National University

Canberra ACT 0200

AUSTRALIA

jack.corbett@anu.edu.au

Tel: +61261258394

Fax: +6126125 5525

A slightly amended version of this article is published in the journal Life Writing 


\section{Practising Reflection: Empathy, Emotion and Intuition in Political Life Writing}

Attempts to unravel the relationship between scholar and subject are common in life writing and underpin the emphasis on reflexivity in interpretive research. However, while the conceptual basis for reflexive practice is well established, there is less written on how it is actually done. In this article I reflect on how I created a collective portrait of politicians in the Pacific Islands. My rationale for describing how I produced knowledge in this project echoes the call for interpretive researchers and biographers, who wish to become reflexive, to engage in and describe reflexive practices. In doing so, I illustrate how empathy, emotion and intuition shaped my sources, analysis and writing, and argue that these non-objectivist tools, reflexively considered, have the capacity to enhance our descriptions of the lives we choose to portray.

Keywords: interpretivism, reflexivity, collective portraits, politicians, Pacific Islands

\section{Introduction $^{\mathrm{i}}$}

I have seen enough of politics at work from close range, enough of the role that contingency, emotion and sheer stupidity play in human affairs so as not to rush to judgment. I have seen enough decision-making done on the run, in the heat of the moment, without the privilege of leisurely reflection and detailed research, to approach the past with a proper sense of humility (Lal xv).

... biography is not solely a quest to imagine and transform the other. No. It is also a quest to understand and transform the self through a journey mediated by feeling and self-discovery (Morley 79).

Attempts to unravel the relationship between scholar and subject are common in life writing and underpin the emphasis on reflexivity in interpretive research practice. In this article I do 
not propose to revisit debates about whether empathy, emotion and institution should play a role in research practice - I take it as a given that they do (for a review of this debate see Stueber; Yanow; Zahavi) - but instead reflect on how empathy, emotion and intuition informed my collective portrait of politicians in the Pacific Islands. My rationale for describing how I produced knowledge in this project echoes the call for interpretive researchers and biographers who wish to become reflexive to engage in and describe reflexive practices (Hendriks; Bacchi). I recount how different qualitative sources - published life histories, in-depth interviews and observation - provided different insights and elicited certain emotions. I narrate how these diverse storytelling types were analysed and combined, including how I assessed the plausibility of knowledge claims, and explain how I grappled with the tendency of both interpretive research and collective portraits to generate a sense of narrative homogeneity. Woven through this description of the joys and challenges that I encountered whilst conducting research on politicians and political leaders across the Pacific region are my reflections on how I have been changed by the process, not just as a scholar but as a human being.

\section{The Project: A Collective Portrait of Politicians in the Pacific Islands}

Before I begin this discussion let me provide a brief outline of my project. The aim of my research was to gain a politician-centred view of political life in the Pacific Islands. Politicians are commonly blamed for many of the problems that Pacific Island nations face and yet we know very little about them: how and why they get into politics, what it is like when they get there, and why they stay and leave. Not that popular disillusionment with elected officials is confined to the Pacific - quite the opposite. However, this critique tends to be sharpened by the normative imperatives of the development enterprise which emphasise improvement, growth and reform. Consequently, given economic constraints, politicians 
reflect that they are often unable to deliver material gains that match rapidly growing constituent aspirations, exacerbating discontent. Ultimately, my 'insider’ view of politics was intended to function as a counter-narrative that might temper dissatisfaction and restore a degree of respect to the people who occupied public office. That is not to say that holding public office in the Pacific Islands lacks social status or prestige. Many individuals, especially those of the independence generation, are revered, but being put on a social pedestal does not mean they escape the stigma that tends to follow politicians as a group. Given my aims, as far as possible I sought to remove the artificial line that separates scholar and subject. Using an interpretive approach, I sought to understand politics from the perspective of the individual politician. It was their voice I was interested in, their stories and experiences.

The term collective portrait provides what Patrick Weller (183) calls an 'amalgam of views, a majority voice constructed by the author as a representation of the spectrum of opinions' expressed across forty published life histories (largely autobiography and biography). Settling on politicians was heavily influenced by Grant Reeher's empathetic portrayal of the meanings and beliefs that United States legislators ascribe to their work. Patterns and themes identified by looking across published life histories have been complemented by more than 100 indepth biographical interviews with politicians, past and present, combined with other publicly available materials, participant observation, speeches and newspaper reports. I also benefited from numerous conversations with state, provincial and local government politicians, family members of politicians, biographers, journalists, party officials, senior civil servants and heads of department, consultants and academics.

Interviews and observation were undertaken in Samoa, Fiji, Palau, FSM, Marshall Islands, Solomon Islands, PNG, Tonga, Kiribati and Nauru, and with retired or transiting politicians 
in Australia and New Zealand. The scope of observation reflected the fluid nature of party politics in many Pacific countries, and the relatively small size of parliaments. In the case of Westminster democracies, most of the leaders I interviewed had held ministerial positions (almost 100 of the 150 or so stories were ministers, prime ministers or heads of state). With one exception, interviews were all conducted in English, although, by and large this is not the language of political assemblies and campaigns. While broadly covering the region, this portrait relies on the experience of post-independence leaders, and politicians from Melanesia and Fiji in particular, partly reflecting the availability of published life histories. ${ }^{\text {ii }}$

Finally, I will outline what I mean by an interpretive approach. Interpretive research is based on the ontological conviction that actions and practices are shaped and framed by ideas held individually and collectively about the world (Bevir; Bevir \& Rhodes; Yanow; Yanow \& Schwartz-Shea). Politicians, in this view, encounter the context in which they find themselves through a veil of ideas, in the same way that the scholars of politics do (Hay; Yanow \& Schwartz-Shea). For interpretivists, the study of political life entails interpreting the beliefs and desires of human actors from within existing governing traditions or webs of beliefs rather than attempting to sit outside and make objective judgements (Bevir \& Rhodes 18). It is typically based on constructivist-subjectivist rather than realist-objectivist prepositions (Yanow \& Schwartz-Shea 33). The scholarly aim in interpretative research is understanding, generated by establishing the beliefs and meanings which inform actions and practices embedded in traditions that bind 'situated agents' together in often unacknowledged intersubjective communities that are open-ended and evolving (Hay 167): the 'situated agent' reflects on their own beliefs and acts for their own reasons, albeit the meanings and beliefs that inform their actions are embedded within a particular context or background of inherited traditions (Bevir \& Rhodes). 


\section{Sources and Insights}

It is axiomatic but nevertheless important to note that different sources generate different insights - this is the logic behind the idea of triangulation for example - but it is also true that they provoke varied reactions from the researcher. In this project I collected three main types of data: published life histories, in-depth biographical interviews and observation-based research. Each provided different insights but also elicited different emotions and presented unique challenges to the researcher. Let me start with life history writing.

The subjective nature of life history writing makes it a somewhat ambiguous genre in the disciplines of history and political science. Approaching politics from the perspective of the human actor can provide a sense of what Dovra Yanow (579) calls 'passionate humility' - an appreciation of the triumphs and joys of political life, but also its challenges and pitfalls. For scholars attempting to uncover the truth about an event or write objective analysis about a period of time, the apparent biased and self-serving nature of life history writing - evidenced by the numerous chapters dedicated to justifying key decisions - has its drawbacks. From my perspective, life history has obvious strengths. If each author, editor or 'ghost writer', by getting close to their subject, was able to get a better understanding of who they are and the way they acted, a collective study draws authority from the cumulative acknowledgement of their findings. Moreover, attempts to justify key actions and rationalise crucial decisions provide insights into how politicians think about their world. Regardless of whether or not a narrative is objectively 'true', reflections are nevertheless revealing in that they represent a vision of how the subject wishes to portray themselves and an image of how they seek to be remembered (Mahler 283).

Let me provide two examples to illustrate this point: electoral defeat and legacy. Most of the life histories included in my portrait gloss over electoral defeat. Career pathways and 
foundational experiences fill these volumes, as do descriptions of victorious election campaigns, but defeats generate relatively fewer sentences and paragraphs; they are rarely glorious and unless they form part of what Shamir et al (21) call a 'struggle' narrative, most politicians would prefer they are forgotten. There are a number of ways we can interpret this finding. Certainly it provides a sense of the collective ego of politicians, but it also allows us to recognise that defeat is painful and emotionally sensitive, providing an insight into the human dimension of political life.

Secondly, a key concern of life history writing is legacy, and as many of the political leaders captured in these accounts are the 'founding fathers' of their respective nations, legacy looms large in their stories, and their rationale for writing them, as former Deputy Prime Minister of Vanuatu, Reverend Sethy Regenvanu (4) reflects: 'I realised the risk confronting all of us - of losing the history of one of the most important periods of our life as a people and as a nation.'

In this respect, life histories are more than just stories of politicians; they focalise wider ideals, values and aspirations, and in the case of independence leaders embody the story of a nation (Holden, Morais). Echoing R.A.W. Rhodes (48), the insight into the formation of political identity, albeit subjective or inter-subjective, that is provided by looking at life history through the prism of legacy, is of great benefit to interpretative research.

Reading life history can be both enjoyable and informative but also frustrating and dissatisfying. Not every life history I read to compile this portrait contained fascinating insights, but most were entertaining. I laughed at the humorous anecdotes and felt the pain of their despair. In this respect politics and storytelling have an elective affinity, as they are both consumed by a public eager for drama, and life history provides a reminder that it is the passion and emotion of this performance that enthrals the audience. Recognition of this performative link between leader and follower has heavily influenced how I have presented 
the social contract in my portrait, including my discussion of practices commonly labelled as corrupt: 'bribery', ‘vote buying' and other forms of 'money politics'.

Conversely, while these texts provided insights and examples that were invaluable for my project, ultimately they were not tailor made for my aims. I could ask questions of these texts but the answers were not as focused as those elicited during interviews. In this respect, relying upon the public record put me in a similar position to a biographer who seeks to reconstruct the life of an historical figure - no matter how rich the archive, in the end there were still questions that I wished I could have asked and answers that I would have probed further. In particular those life histories that conclude with their subject winning election books by Dame Carol Kidu or Dr Gideon Zoloveke for example - were particularly frustrating. I wanted to know more: Was being a politician what they expected? Did they achieve what they set out to do? Did it change them as a person? In some cases, like Grand Chief Sir Michael Somare or Father Walter Lini, the publication of their autobiographies around independence is revealing insofar as they speak of promise for the future and the ability of Pacific Island governments to forge their own destiny. In contrast, contemporary discourse around leadership in the Pacific Islands is generally looking back, seeking to regain the optimism and purpose of that period. ${ }^{\mathrm{iii}}$

Despite the importance of these insights, I continue to wish I knew more. In particular, given that most of the independence generation who held office for much of the late $20^{\text {th }}$ Century at some period faced accusations of corruption and abuse of office, I would love to question them further on these issues: How did they approach these decisions and the ethical dilemmas they entail? How do they rationalise or justify their actions? Was the compromise worth it? Did the benefits outweigh the costs? 
The endogenous limitations of relying solely on the public record are one of the many reasons why I chose to complement the rich collection of life histories brought together in my project with in-depth biographical interviews. Interviews afforded me the opportunity to ask questions that the public record could not answer. They enabled me to probe deeper, press harder and ultimately come to a more nuanced understanding of politicians and political life. Interviews, however, are not without their own shortcomings and I am commonly asked how I knew when politicians were being frank and when they were manufacturing ‘spin’ - the assumption being that they are more accomplished liars than us mere mortals.

There are a number of ways to answer this question. The first is the most straight-forward (and yet paradoxically seems the most contentious): my portrait is not a realist-objectivist exercise that seeks to identify good or 'bad' politicians - I am not the judge, jury or executioner. My aim is to provide only one side (the politicians') of an inherently complex story. I do not deny that there are many alternative and often critical viewpoints, but rather claim that there is value in documenting politicians' perspectives, given their centrality to any democratic system and the aforementioned vocality of popular critique. As a result, rather than undermining my findings, self-justification was necessarily encouraged in this instance.

Secondly, despite my presence, the analytic contribution of this portrait lies in the patterns that emerge from this material. Combined, they provide a more nuanced account of political life that privileges meanings and beliefs over cold facts and dead variables. However, to facilitate as frank reflections as possible I undertook to not use names in any publications, and as far as possible supress the identity of the person I was interviewing. Some politicians appreciated this and conceded they would not be prepared to talk without such a guarantee. Others were disappointed they would not be named. In the end, as I will outline below, this trade-off remains both a limitation and a strength of a portrait-style approach. 
Despite this fairly conventional defence, scholars who privilege formal laws and predictive modelling provided by more 'scientific' approaches still treat my unwillingness to ‘triangulate' or 'objectively' verify the claims politicians make about their actions with suspicion. Some reviewers have described pieces of my work (Corbett) as ‘airy’ and producing 'meagre harvest' due to the methodological stance I adopt. The plausibility of my findings is rarely questioned but they remain wary of the hidden empathy I have for my subjects. This, in itself, has been incredibly frustrating particularly given that I don't think my empathy is hidden at all. I am quite comfortable stating that I believe being a politician is a much tougher job than most of us want to admit and that I am therefore broadly sympathetic to those who are willing to be involved. And yet, my frankness only seems to exacerbate their concerns (many would prefer I was less reflexive).

Putting the reception of this type of material aside, conducting interviews can be an intensely emotional experience. As all interviewers will attest, some go better than others. Background information was often hard to access, which meant that I had to be extremely attentive and dextrous with my questioning. It is inevitable that in some instances I missed crucial information. In particular, on days when I had four or five interviews in a row, fatigue played an enormous role in my alertness. My notes recall frustration that I had possibly left important details unquestioned and crucial insights unsaid when conducting the last interview of a long day, often quite late at night (see also Hendriks 284). This, however, is one of the joys of elite interviewing: you often don't get the opportunity to choose when an interview will occur and for how long it will last. Interviews that were organised weeks in advance would be cancelled or shortened while chance meetings often lasted hours. Put simply, and here I owe a great debt to Richard Fenno's ("Watching Politicians”) timeless advice on this topic, I took what I could get, spoke to as many people as possible, and in the process slowly pieced together a story that answered my research questions. What comes flooding back as I 
read over the transcripts is the range of my emotions: one minute I was in the midst of an existential crisis, unsure of what I was doing, whether I would be able to interview enough people, or frustrated that what I heard wasn't making sense. The next I rode a wave of euphoric relief, consumed by my excitement for the topic, the insights I had gained, the things I had seen and the people I had met.

My interviews, however, were not just ‘elite’ interviews - they were also biographical interviews, and this second category is central to my experiences as a researcher. Robert Atkinson (25) argues that the life history interview is unique in that most interviewees are eager to tell you about themselves as it is a subject with which they are intensely familiar. I too found that interviewees said they enjoyed our conversations, with many commenting that they found the opportunity cathartic while others thanked me for asking questions that nobody had asked them before.

Now that I have completed the project, and my anxiety about whether I could pull it off has abated, I recall the warmth of our discussions and the jokes we shared - when I re-listen to the recordings of our interviews I am always surprised by how often we laughed. My research plan records the questions that I wanted to answer and the hunches that I wanted to explore. What I didn't expect was that I would learn so much more - about life and its purpose, about work and its value, about politics, and not just theirs but mine. Not everyone was nice, not everyone was helpful, some turned me away and a few people were especially mean-spirited. But most gave their time freely, many went out of their way to assist me with no obvious reward, and for that reason I am heavily indebted and grateful, for both their insights and friendship.

Intimacy, however, comes at a price: by entering into a conversation the researcher can be both the interrogator and the interrogated and I certainly found that my own motivations and 
aspirations were frequently examined by interviewees. I found that asking people about their lives, including what they believe to be the purpose of their existence (why they became involved in politics), invites all manner of reflections. In particular, given that I was younger than most of my interviewees, many took the chance to impart sage advice (in most cases it was appreciated). However, in many cases such interactions were quite confronting. What do I consider to be the purpose of my life and how do I know that I am fulfilling it? Let me provide one example to illustrate this point.

In his reflections on editing the lives of two prominent Solomon Islander leaders - inaugural Prime Minister, Sir Peter Kenilorea, and former Governor-General and Minister, Nathanial Weana - Clive Moore reflects on how he grappled with the religiosity that filled their texts (particularly the reliance on dreams and premonitions in the case of the latter). Ultimately, he concludes, despite his discomfort (he describes himself as a 'lapsed Christian’), this aspect of political life in the Pacific Islands must be incorporated into our accounts as it is crucial to understanding these men and the people they represent, despite the reaction such sentiment usually attracts from the academy (I have been warned off the Kenilorea book by some colleagues on the grounds of its extensive biblical references).

Faith and spirituality is also a prominent theme in my work but my experience differed from Moore’s, as I am a regular church-goer. Interviewees regularly asked me if I was a Christian and my affirmative response was usually met with a mixture of surprise and delight. What was more confronting, however, were those who assumed that I would not share their faith and so used interviews as an opportunity to proselytise. The sceptics noted above will say that this is proof that politicians are the worst kind of hypocrites (wanton drunkenness and adultery are the usual counter claims). Maybe they are. As Niccolò Machiavelli (135) famously argued, it is important that leaders appear religious. But, like Moore, I am reluctant 
to dismiss this sentiment on the grounds that it is entirely fabricated or disingenuous. If it matters enough to so many of my interviewees who come from a range of backgrounds, then it is important to my portrait. But, despite writing this aspect of political life into my story, these reflections still make me uncomfortable. I cannot ever imagine evangelising as they did. Nor do I see my life as the fulfilment of a preordained destiny. I could put the differences down to theological interpretation or cultural norms - in general Australians do not talk openly about spirituality - but deep down I suspect they are just braver and more devout than I am.

The final form of data generated in this research came from observation. Since Fenno's classic Home Style, some political scientists have used observation-based techniques to generate insights, the increasing popularity of which is now referred to as the 'ethnographic turn’ (for selected examples see de Volo and Schatz; Rhodes "The Everyday Life of a Minister"; Wedeen). Given that I wanted to gain an insight into what politicians do, every opportunity I had time to spend with politicians was a form of observation. While I had defined periods of 'looking over their shoulder' on the campaign trail in Samoa, at regional meetings in Palau, Tonga, Australia and New Zealand, in parliament in Kiribati and in the constituency in Marshall Islands, I also learnt a lot about what politicians do when conducting or waiting to conduct interviews.

For example, in interviews politicians told me how they had little privacy - that wherever they went they were asked for favours and money - but this really only hit home when I saw it: when I walked down the street, or was sitting in their home or office, and constituents arrived asking for money (and were usually sent away with cash). Politicians talk about campaigning strategies but I only really appreciated how it all comes together when I went with them as they asked for votes and sat with their families as election results were 
announced. They regularly talk about how much fun overseas travel is but I only understood why as we swapped stories over drinks at regional meetings. Moreover, the constraints placed on them by geography loom large in accounts of their frustrations with political work, but I only grasped the enormity of the Pacific once I travelled across it, just as I didn’t really understand how hard it is to make reliable travel plans until my own schedule was ruined. For me, observation grounded the portrait in everyday political life, providing a greater degree of confidence and understanding in what I was hearing in interviews.

The observer, however, is situated differently to the interviewer or the reader of life histories, as the political world is not entirely filtered through the politician's gaze. I was present, and so observation necessarily involved seeing beyond politicians’ descriptions and selfjustifications - I saw what was happening and I cannot say that my portrait has been unaffected by this wider scope. For example, money politics, according to almost every politician, is on the rise in the Pacific region. I knew I would see it. I understood all of the arguments for and against. I thought I would be unperturbed. But, watching the cash being handed over to voters still made me uneasy. There are a number of ways we can interpret this. Obviously it provides an insight into how I understand and value both money and elections. Beyond that, however, the intentionally public nature of this largesse is important to how I interpret political practice in the Pacific Islands. Echoing my earlier reflection about political performance, if corruption is secretive by definition, then the label needs refinement in the Pacific, as activities commonly labelled corrupt in terms of the legal-rational ideal are often intentionally conspicuous in this context.

'Being there' also brought me into contact with the full range of people who work with politicians on a daily basis: advisors, civil servants, journalists, academics, family, constituents, donors and diplomatic officials. These latter interactions were particularly 
revealing. Almost everyone from taxi drivers to departmental secretaries has an opinion about the current crop of parliamentarians and these views are rarely complimentary. Inevitably, however, the strongest criticisms came from donors and diplomats. Not that I should tar everyone with the same brush - many were privately as appalled as I was - but the outright paternalism and thinly veiled racism of these individuals disgusted me more than any amount of largesse. Again, this reflection can be interpreted in a variety of ways. It certainly says something about my values, although, given my stated aims, my reaction probably will not come as a surprise. But, the frequency and intensity of this response has fundamentally shaped how the sources and insights used to compile this portrait have been understood, as the sharpness of this critique stiffened my resolve to confront this version of anti-politics, (even if at times my courage wavered at the thought of what these same people might say if they ever read my work) as I write in the book's introduction:

"Everybody has an opinion on what constitutes good and bad politicians. These opinions vary widely according to the views each of us holds about how we ought to be governed. Yet, despite this diversity, or perhaps because of it, populist negativity towards politicians as a group persists, even though we often have an affinity with certain individuals, political parties or ideologies. These prevailing negative perceptions and the predominantly low value attached to politicians and political work is what interests me, and so I set out to find out more about those people who are supposed to epitomise the promise of representative government but regularly find themselves cast as the antithesis of every virtue that system seeks to uphold.”

\section{Storying Telling, Intuition and Analysis}

So far I have illustrated how emotion and empathy have influenced how I have interpreted and understood the insights provided by different sources. Emotion and empathy are also 
important to how we think about data analysis, but of more significance is the role that intuition plays in this process. In defending an interpretive approach against other methodological paradigms, scholars working in non-objectivist traditions have tended to argue that their analysis is still systematic despite its constructivist foundations. However, as John Boswell and I have argued elsewhere, this can dramatically understate the role that intuition - think hunches, instinct and 'gut feel' - play in this process.

For the most part data analysis began as I selected quotes, sorted them into categories and then wrote around them. However, unlike projects where the design, collection and analysis phases are entirely separate, in this case they were intimately intertwined (Yanow; Yanow \& Schwartz-Shea). Reading life histories began before I had decided on my research questions, for it was partly on the strength of what questions I thought these texts could answer that I designed my project; and I am still conducting interviews even though I have started to publish my findings. Moreover, rather than departmental seminars or conference papers, the first time I presented my emerging theories was during interviews, with interviewees providing instant feedback on whether the patterns and divergences that I identified reflected their experiences (some later read and commented on draft chapters and papers). As outlined above, what emerged from life histories and early interviews and observations was the performative aspect of political life - politicians modify their style, dress, and language to suit the occasion. Some politicians agreed with this depiction, but others did not, and argued that this characterisation assumed they were disingenuous. In the end, as the following extracts highlight, both views were included in the final manuscript as both are important. For some politicians, politics is a game in which they might play a variety of characters: 
“...politicians adopt and foster certain images or styles: they dress or speak differently according to the setting. Henry's gregarious personality, for example, was part of his persona, as [Ratu Sir Kamisese] Mara (27) recalls:

"The early days of the Forum were memorable to me because of the performance of Albert Henry. He livened up the party. Every time he got the worse for drink two or three of us would have to take him to his room to help him with the problem of his wife. One of us would knock on the door and say he had talked late into the night in a very happy mood. Albert used to feign heart attacks to trick his wife. At Rotorua he had a real heart attack and we had great difficulty in convincing his wife.”

Styles can also change over time with the biographers of both [Sitiveni] Rabuka and [Jai Ram] Reddy explaining how each altered their approach and outlook in light of events and circumstances. Political leaders can also re-invent themselves, with [Sir Michael] Somare’s political obituary written almost as many times as he returned reincarnate.”

Others believe they stay true to their values and beliefs, and maintain that their participation has left them fundamentally unchanged:

“Most politicians are also equally adamant that politics isn’t necessarily a ‘dirty game'. 'I have to sleep at night' is the phrase regularly used to explain how they balance business interests and political decisions. They tend to concede that power can corrupt, that elections in particular can be dirty, that holding office opens them up to temptations they would not otherwise face, and that they are not totally innocent. But most also maintain that it does not necessarily corrupt, and that they have preserved their morality or what Stephen Garrett might call their 'intuitive values’.” 
Significantly this contrast, along with many similar reflections like it, underpins my belief that disillusionment with politicians as a homogenous group overlooks the plurality of people who enter parliament.

It was through this process of comparison that I gained confidence in my interpretations and overarching narrative. I knew the patterns I was observing were meaningful when I heard them in different times and places. In particular, life histories and interviews with past politicians enabled me to draw out historical themes, providing a similar longitudinal dimension that I found so compelling in other collective studies. However, these responses were not coded or counted - my sample is in no way 'representative' - and so judgements about the strength of one theme over another stem from my inmersion within this material over a long period of time. Moreover, as my exposure increased, I became more interested in certain experiences or characteristics - a politician from a particular country, for example, or a politician who had just been defeated - and so I addressed questions specific to their importance within my overall story, with the previous stories giving order and meaning to the life being told (Atkinson, Rouverol). The above extracts illustrate how this approach and its reliance on intuition has impacted on my final portrait, with adjectives such as 'some', 'others', 'most', 'a minority of' reflecting my interpretation of the mountains of material I waded through. As far as possible I use quotations to support these assessments, while others seeking to validate my views are welcome to read the published material. However, the interviews and observations remain accessible only to me.

My sense is that this, when coupled with my stated empathy, is what concerns others about my approach. I do not claim to be one-step removed, impartially weighing conflicting accounts. For the majority of the material I was physically present as it was recounted and I remain emotionally and intellectually bound to those moments. It is my story as much as 
theirs: we created it together. In this respect my aims - to produce an account that politicians themselves would recognise as authentic - is crucial here. The standard I set myself was to produce a story that we can imagine or feel is right, rather than scientific proof. I do not claim to have reached the bottom of any issue in one interview. Rather, the story was pieced together via countless conversations, with each insight, admission and reflection helping to fill in parts of a much broader picture. As such, certain interviews provided more clarity than others, but all in some way contributed to the overall story. I do not deny that in cases where access was precarious I avoided sensitive matters. On other occasions, where I was more confident, I pressed harder. Unavoidably, however, this portrait is biased by the level of access I was granted.

Having said that, throughout I regularly doubted my intuition - a point best illustrated by the relatively large number of interviews I conducted. I initially aimed to conduct around twenty interviews, providing I could get a regional spread, that when added to the life histories would provide a relevant insight. In contrast, with the more than 110 primary interviews, along with countless peripheral conversations, observations and published material, I ended up collecting far too much information. There are two main reasons why I pushed well beyond 20 interviews. The first is simply that I was enjoying it, and while I had the time and resources I was keen to continue. As Atkinson (22) highlights, the process of telling a life story with another person can be one of the most satisfying and insightful interpersonal research experiences. In particular, because of the timing of this research, I had the privilege of interviewing a number of the region's 'founding fathers'. In another decade somebody conducting similar research will quite simply not have this opportunity.

The second reason why I persisted was because from the beginning I had nagging doubts about the representativeness of my sample. Representativeness is not usually associated with 
interpretive research but my concern reflects a desire to do justice to the diversity of the region. In hindsight I could have limited the scope to one or two countries but in truth the amount of data I was able to collect was partially contingent on being relatively unconstrained in whom I could talk to. However, despite the amount of material collected, and my instinctive belief that the returns of undertaking more interviews have substantially diminished, to some extent the nagging questions about representativeness remain. I know that a few more interviews would not change the overall picture or alter the general themes but, I continue to speculate, would they alter a sentence or a paragraph? The conventions of a qualitative approach dictate that the researcher will reach 'saturation point' when they stop hearing anything new from interviews. In some respects, 20 interviews was enough to reach this point as the main parameters of the study were fixed by then. And yet, every life is unique and, given that my interviews were at best semi-structured, I nearly always learnt something because I tended to ask new questions. When I look back, reliance on intuition left me both mollified and agitated - I knew I had a story to tell but remain nervous about how I have told it, what it means, and how it will be received.

\section{Narrative Homogeneity and Authorial Voice}

Reflecting on the presentation of collaborative research approaches, and specifically oral histories that treat interviewees as experts, Michael Frisch (113) wonders who the author is in such accounts. A similar question could be asked of my portrait: by privileging the voice of the politician, have I written a collective portrait or an authorised collective portrait? Obviously, the former implies greater objectivity than the latter, which is inherently subjective or inter-subjective. Following Valarie Yow (71), in explaining how I have compiled this portrait, including my epistemological commitments, data collection and analysis, I have tried to frankly account for my subjective presence in this research. Despite 
my attempt to stay as true as possible to the voice of the politicians I spoke to and the things I saw, I believe, to quote Colin Hay (168), that it is my 'interpretation of interpretations'. The views and reflections may be theirs but I have taken those conversations and experiences and used them to support and challenge certain theories and approaches, which many of them won't necessarily care about or understand. I am increasingly conscious that my voice is the unifying one and that most of the people I spoke to have little sense of the shared experience that I claim exists. Moreover, there is some merit to this objection. Social scientists may point to the linguistic and cultural links that underpin the label 'Oceania', 'South Pacific' or 'Pacific Islands', but Palau is a long way from Cook Islands and so I can appreciate why some politicians may see little relevance in the categorisation.

More generally, this sense of homogenisation is a limitation of my approach. Collective portraits can, as Weller (183) concedes, only take us so far. Most obviously, they lack depth, as it is not possible to reproduce all of the interviews or life histories. Behind my portrait are a number of individuals, each with their own experiences and views, each with their own vision of who they are and what they are doing, the uniqueness of which is compressed when put in the context of the group (Walter 8). The danger then is that abstracted concepts that help to explain the experiences of the group can lack the meaning granted to them by an individual account. As Carolyn Kraus (284) illustrates, from the perspective of the person whose life is being written, their experiences and sense of who they are can be twisted and distorted, unrecognisable to those who know them. In addition, from the perspective of academic inquiry, generalisations and patterns that emerge from a collective study can become predictable, even banal, as the author seeks to insert numerous caveats to simultaneously capture general themes and individual diversity (Walter 8). 
When writing, I sought to mitigate both of these tendencies by drawing extensively from quotations, thus allowing these leaders to 'speak for themselves', in the belief that an individual's reflection can bring to life a more generalised category. However, the shortcomings of this approach remain, and, despite the fact that I have used their words, I am increasingly uncomfortable with the claim that leaders 'speak for themselves' in my portrait. Indeed, in the process of creating a collective narrative, I have come to accept that in many respects I am speaking through them. That is not to say that responses have been entirely decontextualised - I understand individual beliefs to be situated within inter-subjectively held patterns of meaning - or to deny how immersion in the data has informed my overarching narrative; as outlined above, this portrait is the product of extensive absorption. Rather, I believe it supports Hay's (171) assertion that in part this sense of narrative homogeneity is embedded within this type of analysis.

In addition, the predisposition of this approach towards consensus was particularly helpful in this project as it enabled me to draw out a shared voice without which any write up would flounder. On the other hand, the extent to which a shared voice exists is contentious. In my portrait I claim that a degree of spatial and temporal commonality exists across an area commonly called the Pacific Islands and over nearly 80 years of parliamentary government. Moreover, what became increasingly apparent as I participated in recounting these stories was that many of the responses were incredibly similar to other politician-centred studies from around the world. To give one example, across the Pacific politicians talk about how politics is an itch: 'once it gets under your skin it is hard not to scratch.' Peter Riddell's British politicians talk about politics as a bug: 'once you get it, it is very difficult to shake off' (8). Despite the seemingly obvious similarity, I approach the interpretation of these claims with some trepidation, given the predisposition of the method towards consensus, but 
also because in the context of this research I am a 'double outsider', neither a Pacific Islander nor a politician. ${ }^{\text {iv }}$

Having said that, there is, I acknowledge, a certain irony embedded in the match between aims and methods in this book. I sought to access and present the human side of political life but in order to elucidate frank reflections from interviewees I gave assurances that, as far as possible, I would supress their identity and not use names in any publications - rendering them relatively 'faceless', as the following extract about how imperfect election strategies can be highlights: ${ }^{\mathrm{v}}$

“ ‘The first time I ran in the elections I got in ... then there was the second elections [and] I continued to see the support remain behind me. So, it went okay again, I got in and now I ... continue to see the same support and I'm sure I will be successful.'

[This politician lost at the election held only a few weeks later]”

And while in most cases I was also able to include the country from which a politician is from, as this quote illustrates, this was not always possible as small parliaments make individual MPs easily identifiable. Consequently, in most instances I follow the conventions for this type of research and withhold background information (Reeher; Rhodes). As seen in earlier extracts, the use of quotes from life histories and other publicly available sources partly mitigates this drawback but, unavoidably, the limitation remains.

Nevertheless, despite these restrictions, I hope the dividends of this trade-off are clearly represented in my published work. And, while different in approach and geographic scope, I hope that the book will be seen as a complementary addition to the existing literature on politics and political leadership in the Pacific region.

\section{Conclusion}


Upon circulating a draft to the subjects of his book Everyday Life in British Government, Rhodes (304) describes how unhelpful some of the comments he received were, highlighting one response in particular that expressed dissatisfaction with his portrayal, and the level of anonymity that he had provided, a concern he dismisses as 'self-serving defensiveness' common to elites and public figures. I conclude with this example not because I am advocating the uncritical analysis of what we see or hear when conducting this type of research, but rather to illustrate the extent to which the production of 'insider' accounts can misrepresent how leaders see themselves and the work they do. In essence, I echo Mark Evans' (271) suspicion that Rhodes' reaction tells us just as much about his feelings toward this particular subject as their inherent 'self-serving defensiveness'. Treating our subjects as 'experts' and 'collaborators' and reflexively accounting for our own part in the final story enables us to grapple with this relationship between scholar and subject as we seek an 'insider’ perspective. However, I believe that this corrective only succeeds if we acknowledge the extent to which our own emotions, empathy and intuition, embedded in both research practice and analysis, inform how we frame our knowledge claims.

To support this point, and to illustrate how emotion, empathy and intuition informed my research practice, I have outlined how I created a collective portrait of politicians in the Pacific Islands. My rationale for describing how I produced knowledge in this project echoes the call for interpretive researchers and biographers, who wish to become reflexive, to engage in and describe reflexive practices (Hendriks; Bacchi). In doing so, I have argued that instead of supressing this sentiment, or attempting to appear more objective than we really are, emotion, empathy and intuition, reflexively considered, have the capacity to enhance our descriptions of the lives we choose to portray. 


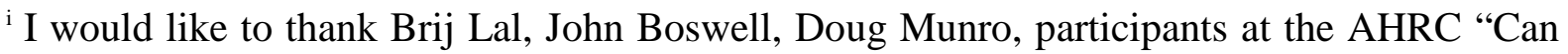
Biography Survive?” conference, University of Southampton, 3-4 July 2012, and the 7th International Conference on Interpretive Policy Analysis, Tilburg University, 5-7 July 2012, and two anonymous reviewers who provided comments on an earlier version of this paper. Any errors are of course my own.

ii This book length project is currently under review with publication planned for 2014.

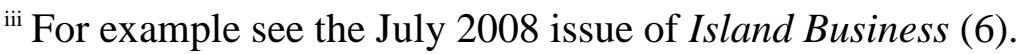

${ }^{\text {iv }}$ Congruent with the emphasis on "who researchers are", my interest in the region comes from having 'grown up' in Fiji during the mid-1990s. I have also observed politicians from close range while working in the Australian Public Service.

${ }^{v}$ In the case of female politicians, for example, nominating their country would make them easily identifiable.

\section{References}

Atkinson, R. The Life Story Interview. London and New Delhi: Sage Publications, 1998. Print.

Bacchi, C. "Gender Mainstreaming and Reflexivity: Asking Some Hard Questions." Advancing Gender + Training in Theory and Practice 2011. Print.

Bevir, M. “Public Administration as Storytelling”, Public Administration 89.1 (2011): 183195. Print.

Bevir, M. and Rhodes, R. A. W. Interpreting British Governance. London: Routledge, 2003. Print. 
Boswell, J. and Corbett, J. “An impressionist’s confession: revealing the brush strokes of interpretive research”. (forthcoming). Print.

Corbett, J. “'Everybody Knows Everybody’: Practising Politics in the Pacific Islands”, Democratization. (forthcoming [2013]). Print.

de Volo, L. B, and E Schatz. "From the inside Out: Ethnographic Models in Political Research." PS: Political Science and Politics 37.2 (2004): 267-71. Print.

Evans, M. "Review: Observing Government Elites up Close and Personal." Public Administration 88.1 (2010): 267-83. Print.

Fenno, R. Home Style: House Members in Their Districts. Boston and Toronto: Little, Brown and Co, 1978. Print.

---. Watching Politicians: Essays on Participant Observation. IGS Press, 1990. Print.

Frisch, M. "Sharing Authority: Oral History and the Collaborative Process." The Oral History Review 30.1 (2003): 111-13. Print.

Garrett, S. "Political Leadership and the Problem of 'dirty hands'.” Ethics and International Affairs 8 (1994): 159-175. Print.

Hay, C. "Interpreting Interpretivism Interpreting Interpretations: The New Hermeneutics of Public Administration." Public Administration 89.1 (2011): 167-82. Print.

Hendriks, C. M. "Praxis Stories: Experiencing Interpretive Policy Research." Critical Policy Analysis 1.3 (2007): 278-300. Print.

Holden, P. "A Man and an Island: Gender and Nation in Lee Kuan Yew's the Singapore Story." Biography 24.2 (2001): 401-24. Print.

Kidu, C. A remarkable journey. South Melbourne: Pearson Education Australia, 2002. Print.

Kraus, C. "On Hurting People's Feelings: Journalism, Guilt, and Autobiography." Biography 26.2 (2003): 283-97. Print. 
Lal, B. V. In the Eye of the Storm: Jai Ram Reddy and the Politics of Postcolonial Fiji. Canberra: ANU E Press, 2010. Print.

Lini, W. Beyond pandemonium: from the New Hebrides to Vanuatu. Wellington: Asia Pacific Books, 1980. Print.

Mahler, M. "Politics as a Vocation: Notes toward a Sensualist Understanding of Political Engagement." Qualitative Sociology 29 (2006): 281-300. Print.

Mara, K, “On Albert Henry” Islands Business (September 1991): 27. Print.

Moore, C. “Solomon Islands Biography: Editors, Co-authors, and Ghost-Writers” in J. Corbett and B. V. Lal (eds) Political Life Writing in the Pacific Islands: Reflections on Practice. (forthcoming). Print.

Morais, D. "Malaysia: The Writing of Lives and the Construction of Nation." Biography 33.1 (2010): 84-109. Print.

Morley, R. "Fighting Feeling: Re-Thinking Biographical Praxis." Life Writing 9.1 (2012): 7795. Print.

Reeher, G. First Person Political. New York and London: New York University Press, 2006. Print.

Regenvanu, S. J Laef Blong Mi : From Village to Nation : An Autobiography Suva, Fiji : Institute of Pacific Studies ; Port Vila, Vanuatu : University of the South Pacific, Emalus Campus2004. Print.

Rhodes, R. A. W. Everyday Life in British Government. Oxford and New York: Oxford University Press, 2011. Print.

---. "Theory, Method and British Political Life History." Political Studies Review 10.2 (2012): 161-76. Print.

Riddell, P. Honest Opportunism : How We Get the Politicians We Deserve London Indigo, 1996. Print. 
Rouverol, A. J. "Collaborative Oral History in a Correctional Setting: Promise and Pitfalls." The Oral History Review 30.1 (2003): 61-85. Print.

Shamir, B., H Dayan-Horesh, and D Adler. "Leading by Biography: Towards a Life-Story Approach to the Study of Leadership." Leadership 1 (2005): 13-29. Print.

Somare, M. T. Sana: an autobiography of Michael Somare. Port Moresby: Niugini Press, 1975. Print.

Stueber, K. "Reasons, Generalizations, Empathy, and Narratives: The Epistemic Structure of Action Explanation." History and Theory 47.February (2008): 31-43. Print.

Walter, J. "Politics, Policy and Change: Biography and the Age of Uncertainty." Australasian Political Studies Association conference. 2006. Print.

Wedeen, L. "Reflections on Ethnographic Work in Political Science." Annual Review of Political Science 13 (2010): 255-72. Print.

Weller, P. Australia's Mandarins: The Frank \& the Fearless? Australia: Allen and Unwin, 2001. Print.

Yanow, D. "Ways of Knowing: Passionate Humility and Reflective Practice in Research and Management." The American Review of Public Administration 39.6 (2009): 579-601. Print.

Yanow, D. and Schwartz-Shea, P. "Interpretive Research: Characteristics and Criteria”, Revue internationale de Psychosociologie, 15.35 (2010): 29-38. Print.

Yow, V. "'Do I Like Them Too Much?": Effects of the Oral History Interview on the Interviewer and Vice-Versa." The Oral History Review 24.1 (1997): 55-79. Print.

Zahavi, D. "Beyond Empathy: Phenomenological Approaches to Intersubjectivity." Journal of Consciousness Studies 8 (2001): 151-67. Print. 
Zoleveke, G. A. P. Zoleveke, a man from Choiseul : an autobiography. Suva: Institute of Pacific Studies, 1980. Print. 